\title{
PEMANFAATAN TEKNOLOGI PENGINDERAAN JAUH DAN SISTEM INFORMASI GEOGRAFIS UNTUK ANALISIS SPASIAL TINGKAT KEKERINGAN WILAYAH KABUPATEN TUBAN
}

\author{
Bangun Muljo Sukojo ${ }^{1}$, Muharrama Putra Prayoga ${ }^{1}$ \\ ${ }^{1}$ Departemen Teknik Geomatika, FTSLK-ITS, Kampus ITS Sukolilo, Surabaya, 60111, Indonesia \\ e-mail: ${ }^{1}$ bangun_ms@geodesy.its.ac.id
}

\begin{abstract}
Abstrak
Kabupaten Tuban merupakan salah satu kabupaten di Jawa Timur yang merupakan daerah rawan bencana kekeringan. Berdasarkan data Indeks Resiko Bencana Indonesia (IRBI) yang dirilis Badan Penanggulangan Bencana (BNPB) tahun 2013, Kabupaten Tuban mendapatkan skor 24 untuk indeks resiko bencana kekeringan, dimana skor tersebut dikategorikan dalam tingkat resiko tinggi untuk bencana kekeringan.

Penelitian ini bertujuan untuk mengetahui sebaran daerah beresiko kekeringan di Kabupaten Tuban dengan memanfaatkan data penginderaan jauh yang diintegrasikan dengan kondisi fisiografis wilayah yang berpengaruh terhadap kekeringan yang kemudian dikelompokkan kedalam 5 kelas tingkat kekeringan, yaitu : sangat rendah, rendah, sedang, tinggi, dan sangat tinggi. Data yang dibutuhkan pada penelitian ini antara lain : peta Normalized Different Vegetation Index (NDVI), peta Normalized Different Water Index (NDWI), peta Land Surface Temperature (LST), peta rata - rata curah hujan, peta hidrogeologi, dan peta penggunaan lahan.

Dari pengolahan data dihasilkan bahwa sebagian besar wilayah di Kabupaten Tuban masuk kedalam kategori kekeringan tinggi yaitu seluas $119.388,50$ hektar atau $60,60 \%$ dari luas wilayah, sedangkan yang terendah adalah kategori kekeringan sangat rendah yaitu hanya seluas 180,48 hektar atau 0,09\% dari luas wilayah.
\end{abstract}

Kata Kunci : Kabupaten Tuban, Kekeringan, Penginderaan Jauh, Sistem Informasi Geografis.

\begin{abstract}
Tuban Regency is one of the districts in East Java which is a drought-prone area. Based on the Indonesian Disaster Risk Index (IRBI) data released by the Disaster Management Agency (BNPB) in 2013, Tuban received a score of 24 for the drought disaster risk index, which scores are categorized as high risk for drought.

The purpose of this research is to know the distribution of drought risk areas in Tuban Regency by utilizing remote sensing data integrated with the physiographic condition of the region that affect the drought which is then grouped into 5 classes of drought levels, namely: very low, low, medium, high, and very high. The data required in this study are: Normalized Different Vegetation Index (NDVI) map, Normalized Different Water Index (NDWI) map, Land Surface Temperature (LST) map, average rainfall map, hydrogeological map, and land use map.

From the data processing, it is found that most of the area in Tuban Regency is categorized into a high drought category of $119,388.50$ hectares or $60.60 \%$ of the total area, while the lowest is the very low drought category that is only 180.48 hectares or $0.09 \%$ of total area.
\end{abstract}

Keywords: Tuban Regency, Drought, Remote Sensing, Geographic Information System.

\section{PENDAHULUAN}

Kekeringan pada dasarnya diakibatkan oleh kondisi hidrologi suatu daerah dalam kondisi air tidak seimbang. Kekeringan terjadi akibat dari tidak meratanya distribusi hujan yang merupakan satusatunya input bagi suatu daerah. Ketidakmerataan hujan ini akan mengakibatkan di beberapa daerah yang curah hujannya kecil akan mengalami ketidakseimbangan antara input dan output air (Shofiyati, 2007).

Kabupaten Tuban merupakan salah satu kabupaten di Jawa Timur yang merupakan daerah rawan bencana kekeringan. Berdasarkan data Indeks Resiko Bencana Indonesia (IRBI) yang dirilis Badan Penanggulangan
Bencana (BNPB) tahun 2013, Kabupaten Tuban mendapatkan skor 24 untuk indeks resiko bencana kekeringan, dimana skor tersebut dikategorikan dalam tingkat resiko tinggi untuk bencana kekeringan.

Untuk mencegah dampak yang lebih luas dari bencana kekeringan itu, maka diperlukan suatu identifikasi daerah rawan bencana kekeringan dengan menggunakan data penginderaan jauh berupa Normalized Different Vegetation Index (NDVI), Normalized Different Water Index (NDWI), dan Land Surface Temperature (LST) yang kemudian diintegrasikan dengan kondisi fisiografis wilayah seperti curah hujan, kondisi hidrogeologi, dan penggunaan lahan. 
Hasil penelitian ini akan menghasilkan suatu informasi spasial mengenai tingkat kekeringan di Kabupaten Tuban dan diharapkan mampu memberikan acuan, perencanaan, dan manajemen penanggulangan kekeringan yang ada di Kabupaten Tuban dan daerah lain pada umumnya serta sebagai pertimbangan penelitian-penelitian selanjutnya.

\section{METODOLOGI PENELITIAN}

Lokasi penelitian pada tugas akhir ini adalah wilayah Kabupaten Tuban, Provinsi Jawa Timur. Kabupaten Tuban secara geografis terletak pada koordinat $111^{\circ} 30^{\prime}-112^{\circ} 35$ Bujur Timur dan $6^{\circ}$ $40^{\prime}-7^{\circ} 18^{\prime}$ Lintang Selatan.

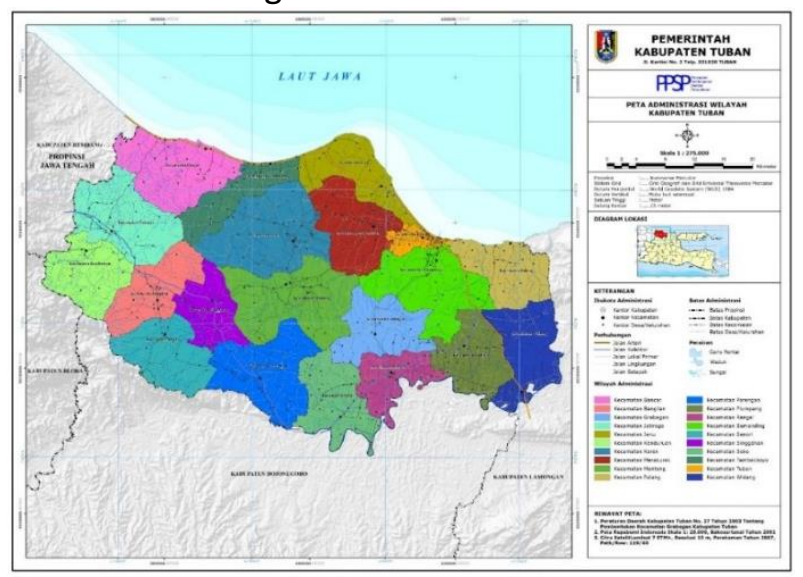

Gambar 1. Lokasi Penelitian

\section{Diagram Alir Pengolahan Data}

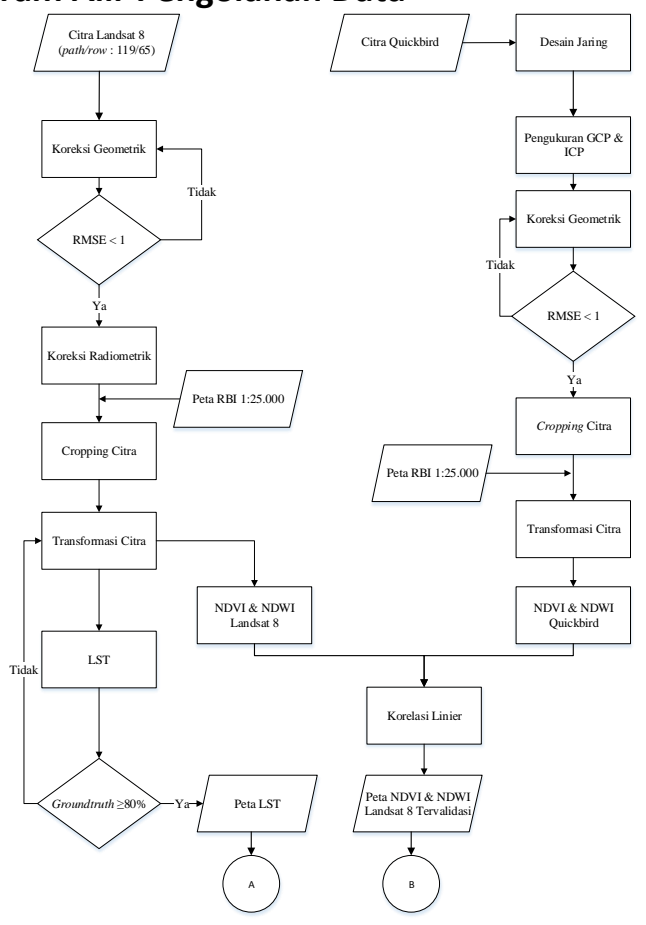

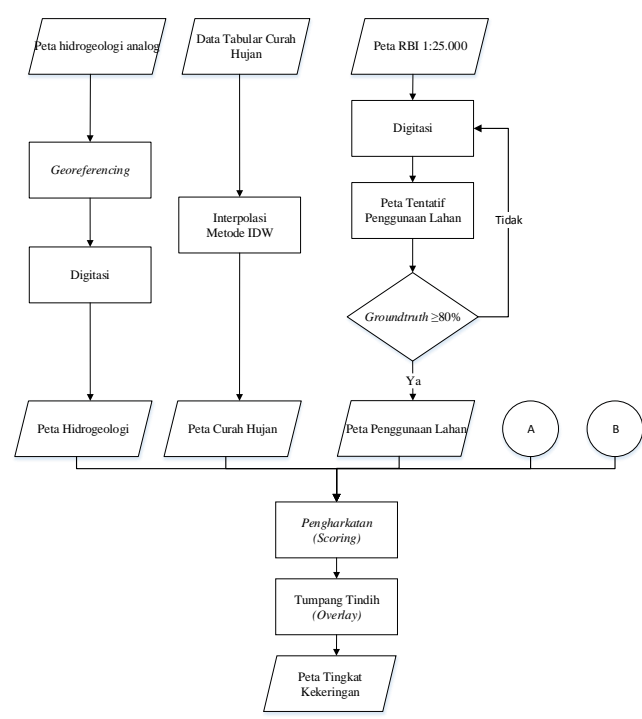

Gambar 2. Diagram Alir Pengolahan Data

\section{HASIL DAN PEMBAHASAN}

\section{Koreksi Citra}

Koreksi geometrik Landsat 8 yang digunakan pada penelitian ini menggunakan metode rektifikasi (image to map) dengan peta RBI skala 1 : 25.000 sebagai acuan. Titik kontrol yang digunakan sebanyak 8 titik yang tersebar di daerah penelitian. Dari hasil rektifikasi ini menghasilkan RMSE sebesar 0,25 , dimana nilai ini sudah masuk toleransi kesalahan yang disyaratkan menurut Purwadhi (2001) yaitu RMSE $\leq 1$, sehingga dapat disimpulkan citra yang digunakan pada penelitian ini sudah terbebas dari kesalahan posisi baik lintang maupun bujur.

Koreksi atmosferik citra Landsat 8 pada penelitian ini menggunakan metode FLAASH (Fast Line-ofsight Atmospheric Analysis of Spectral Hypercubes), dimana metode ini dapat menghilangkan pengaruh gangguan atmosfer dengan memperoleh parameter yang lebih akurat dari reflektivitas, emisivitas, suhu permukaan dan fisik permukaan [7].

Koreksi geometrik citra Quickbird menggunakan 8 titik GCP dan 12 titik ICP, dengan SOF yang diperoleh sebesar 0,178. Nilai SOF ini menunjukkan desain jaring yang digunakan dianggap kuat [3]. Dari hasil orthorektifikasi, didapatkan total RMSE citra Quickbird yang digunakan adalah sebesar 0,72 pixel, dimana nilai ini sudah masuk toleransi kesalahan RMSE yaitu <1 piksel [5].

Indeks Vegetasi (NDVI)

Hasil nilai NDVI pada penelitian ini memiliki rentang nilai antara -0.861224 hingga 0.922975 . 
Semakin rendah nilai NDVI, tingkat kerawanan terhadap kekeringan akan semakin tinggi, sebaliknya, nilai NDVI yang tinggi menunjukkan daerah tersebut mempunyai tingkat kerawanan terhadap kekeringan yang tergolong rendah. NDVI ini kemudian dibagi kedalam 5 kelas klasifikasi [8], seperti tabel dibawah ini:

Tabel 1. Klasifikasi NDVI

\begin{tabular}{|c|l|l|}
\hline Kelas & \multicolumn{1}{|c|}{ NDVI } & \multicolumn{1}{c|}{ Kategori } \\
\hline 1 & $-0.861224 \mathrm{~s} / \mathrm{d}-0.03$ & $\begin{array}{l}\text { Lahan Tidak } \\
\text { Bervegetasi }\end{array}$ \\
\hline 2 & $0.03 \mathrm{~s} / \mathrm{d} 0.15$ & $\begin{array}{l}\text { Kehijauan } \\
\text { Sangat Rendah }\end{array}$ \\
\hline 3 & $0.15 \mathrm{~s} / \mathrm{d} 0.25$ & $\begin{array}{l}\text { Kehijauan } \\
\text { Rendah }\end{array}$ \\
\hline 4 & $0.25 \mathrm{~s} / \mathrm{d} 0.35$ & $\begin{array}{l}\text { Kehijauan } \\
\text { Sedang }\end{array}$ \\
\hline 5 & $0.35 \mathrm{~s} / \mathrm{d} 0.922975$ & Kehijauan Tinggi \\
\hline
\end{tabular}

Hasil peta NDVI bisa dilihat pada gambar dibawah ini :

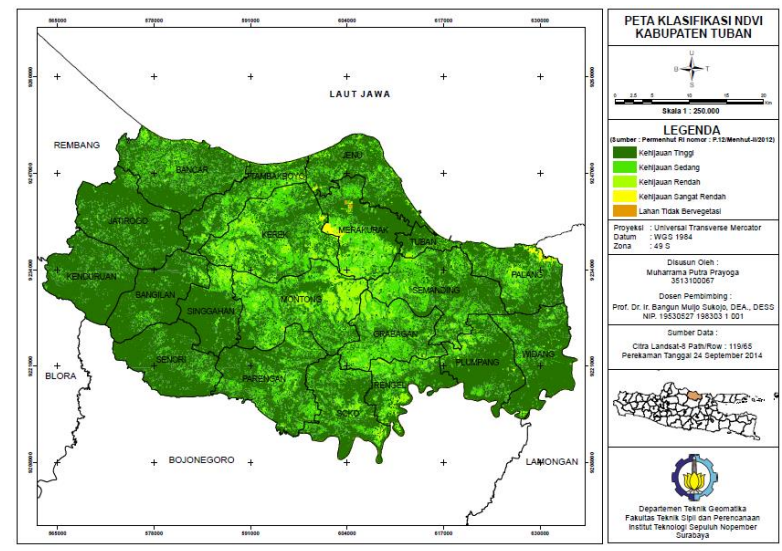

Gambar 3. Peta Klasifikasi NDVI

Berdasarkan hasil klasifikasi, kelas dengan kategori kehijauan tinggi mendominasi daerah penelitian sebesar 110.948,98 hektar atau $56,13 \%$, kemudian kelas kehijauan sedang sebesar 63.708,97 hektar atau 32,23\%, kelas kehijauan rendah sebesar 20.583,13 hektar atau $10,41 \%$, kelas kehijauan sangat rendah sebesar $1.810,07$ hektar atau $0.92 \%$, dan lahan tidak bervegetasi sebesar 596,97 hektar atau 0.30\%.

Nilai NDVI yang telah dihasilkan dari citra Landsat 8 kemudian dibandingkan dengan nilai NDVI yang diperoleh dari citra Quickbird yang memiliki resolusi spasial lebih tinggi, menghasilkan korelasi sebagai berikut:

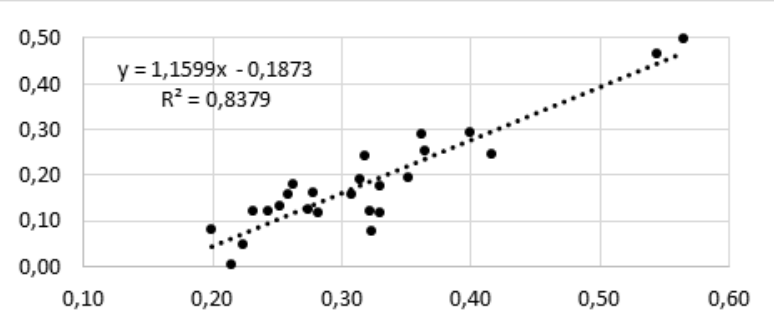

Gambar 4. Korelasi NDVI Landsat 8 dan Quickbird

Hasil korelasi menghasilkan nilai (R) sebesar 0,92. Nilai ini menunjukkan bahwa hasil NDVI antara citra Landsat 8 dan Quickbird termasuk kategori korelasi sangat kuat [9], sehingga dapat disimpulkan transformasi NDVI yang dihasilkan sudah sesuai dengan kondisi di lapangan.

\section{Indeks Kebasahan (NDWI)}

Hasil nilai NDWI pada penelitian ini antara 0.732996 hingga 1 , Semakin tinggi nilai NDWI, tingkat kerawanan terhadap kekeringan akan semakin rendah, sebaliknya semakin rendah nilai NDWI akan semakin rawan terhadap kekeringan. Nilai NDWI ini kemudian dibagi kedalam 3 kelas [10], seperti tabel dibawah ini :

Tabel 2. Klasifikasi NDWI

\begin{tabular}{cll}
\hline Kelas & NDWI & Kategori \\
\hline 1 & $-0.732996 \mathrm{~s} / \mathrm{d} 0$ & $\begin{array}{l}\text { Non-Badan air } \\
2\end{array}$ \\
$0 \mathrm{~s} / \mathrm{d} 0.33$ & $\begin{array}{l}\text { Kebasahan } \\
\text { Sedang }\end{array}$ \\
3 & $0.33 \mathrm{~s} / \mathrm{d} \mathrm{1}$ & Kebasahan Tinggi \\
\hline
\end{tabular}

Hasil peta NDWI dapat dilihat pada gambar dibawah ini :

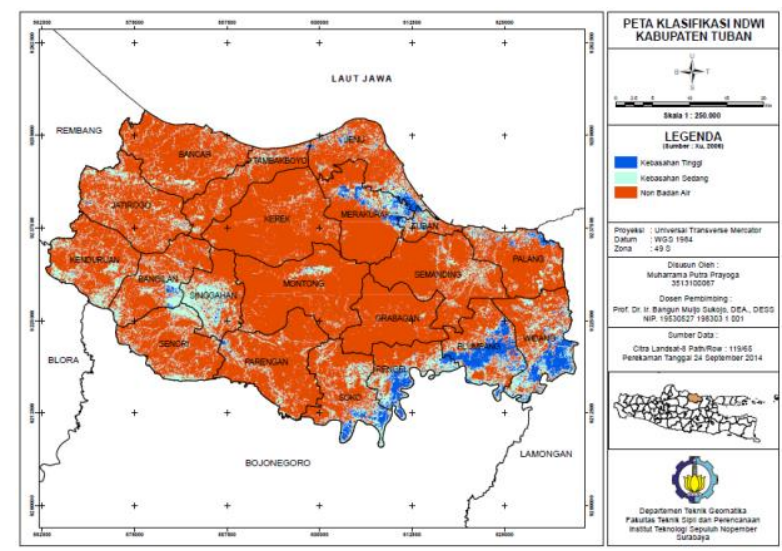

Gambar 5. Peta Klasifikasi NDWI

Berdasarkan hasil klasifikasi NDWI, kelas dengan kategori non-badan air mendominasi daerah 
penelitian sebesar $136.989,86$ hektar atau $69,31 \%$, kemudian kelas kebasahan sedang sebesar 53.897,54 hektar atau 27,27\%, sedangkan kelas kebasahan tinggi hanya sebesar $6.756,08$ hektar atau 3,42\%.

Nilai NDWI yang dihasilkan dari Landsat 8 kemudian dibandingkan dengan nilai NDWI yang dihasilkan dari citra resolusi sangat tinggi Quickbird, menghasilkan korelasi sebagai berikut:

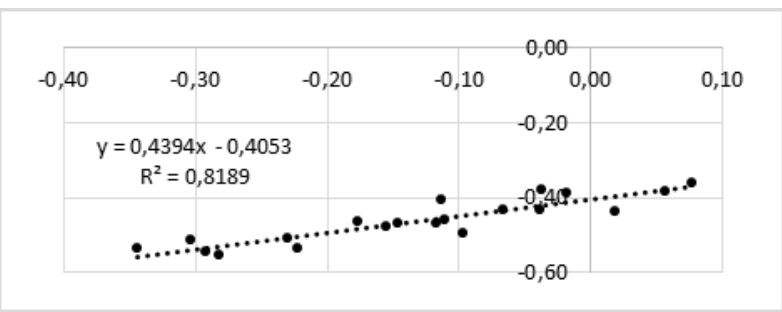

Gambar 6. Korelasi NDWI Landsat 8 dan Quickbird

Hasil uji korelasi NDWI citra Landsat 8 dengan citra Quickbird didapatkan nilai (R) sebesar 0,90. Hasil ini menunjukkan hubungan yang sangat kuat antara kedua citra [9], sehingga dapat disimpulkan transformasi NDWI yang dihasilkan sudah sesuai dengan kondisi di lapangan.

\section{Suhu Permukaan Tanah (LST)}

Dari pengolahan citra, dihasilkan suhu permukaan tanah pada daerah penelitian berkisar antara $26^{\circ} \mathrm{C}$ sampai $51^{\circ} \mathrm{C}$. Semakin tinggi suhu permukaan tanah, resiko terhadap kekeringan akan semakin tinggi. Dari pengolahan citra, suhu permukaan dapat diklasifikasikan seperti tabel dibawah ini :

Tabel 3. Klasifikasi Suhu Permukaan Tanah

\begin{tabular}{|c|c|}
\hline Kelas & Suhu Pemukaan \\
\hline 1 & $26^{\circ} \mathrm{s} / \mathrm{d} 31^{\circ}$ \\
\hline 2 & $31^{\circ} \mathrm{s} / \mathrm{d} 36^{\circ}$ \\
\hline 3 & $36^{\circ} \mathrm{s} / \mathrm{d} 41^{\circ}$ \\
\hline 4 & $41^{\circ} \mathrm{s} / \mathrm{d} 46^{\circ}$ \\
\hline 5 & $46^{\circ} \mathrm{s} / \mathrm{d} 51^{\circ}$ \\
\hline
\end{tabular}

Hasil peta suhu permukaan tanah ditunjukkan pada gambar 6 dibawah ini :

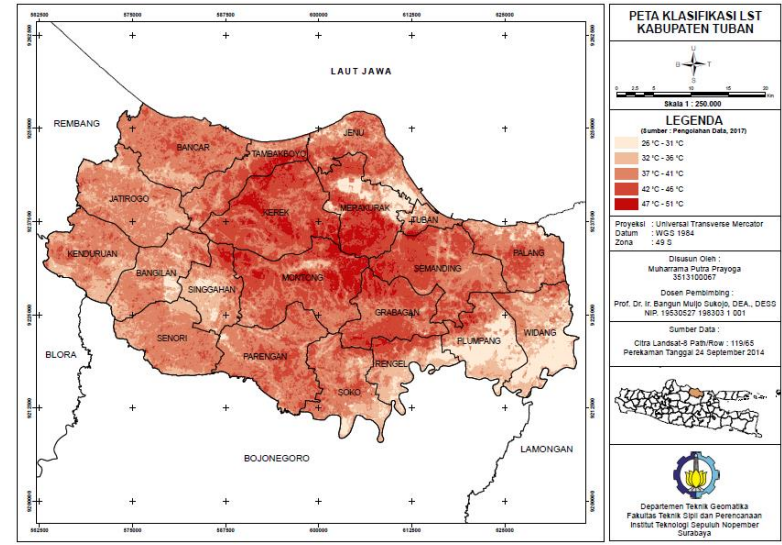

Gambar 7. Peta Klasifikasi Suhu Permukaan Tanah

Hasil suhu permukaan dari pengolahan citra ini tentunya perlu dibandingkan dengan suhu permukaan di lapangan. Dari hasil pengolahan citra dan uji sampel dari 20 titik dilapangan didapatkan korelasi suhu permukaan tanah sebagai berikut:

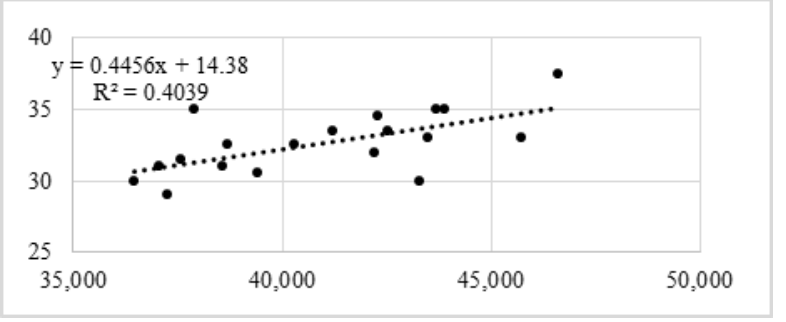

Gambar 8. Korelasi suhu citra dan lapangan Hasil korelasi (R) antara suhu pengolahan citra dan suhu lapangan yaitu sebesar 0.64 , dapat diartikan bahwa keeratan hubungan antara suhu citra dan suhu lapangan adalah 64\%, dimana angka ini termasuk kategori korelasi kuat [9].

Perbedaan suhu di citra dan di lapangan disebabkan beberapa faktor, seperti perbedaan waktu pengambilan data, dimana suhu pada citra diambil pada 24 september 2014 dan suhu dilapangan diambil pada tanggal 6-7 mei 2017, dimana bulan september merupakan musim kemarau, sedangkan pada bulan mei walaupun sudah memasuki akhir musim hujan, tetapi masih sering turun hujan di daerah penelitian. Selain itu, tingkat akurasi alat pengukur suhu permukaan tanah juga dapat menjadi penyebab perbedaan suhu di citra dan lapangan.

\section{Penggunaan Lahan}

Peta penggunaan lahan didapatkan dari hasil digitasi peta RBI skala 1:25.000. Terdapat 12 jenis penggunaan lahan di Kabupaten Tuban yang kemudian disederhanakan dan dikelompokkan sesuai klasifikasi penggunaan lahan terhadap kekeringan [2], menjadi seperti tabel dibawah ini : 
Tabel 5. Klasifikasi Penggunaan Lahan

\begin{tabular}{|c|l|}
\hline Kelas & \multicolumn{1}{|c|}{ Penggunaan Lahan } \\
\hline 1 & $\begin{array}{l}\text { Tanah Terbuka, Lahan Terbangun } \\
\text { (Pemukiman) }\end{array}$ \\
\hline 2 & $\begin{array}{l}\text { Pertanian Lahan Kering, Tegalan, } \\
\text { Sawah }\end{array}$ \\
\hline 3 & Semak Belukar \\
\hline 4 & Hutan, Perkebunan, Tambak \\
\hline 5 & Tubuh Air \\
\hline
\end{tabular}

Kaitannya dengan kekeringan, nilai skor rendah diberikan pada daerah dengan tutupan lahan didominasi oleh pepohonan, sedangkan nilai skor tinggi untuk daerah dengan penutup lahan minim pepohonan atau tanpa pepohonan [2].

Hasil peta klasifikasi penggunaan lahan dapat dilihat pada gambar dibawah ini :

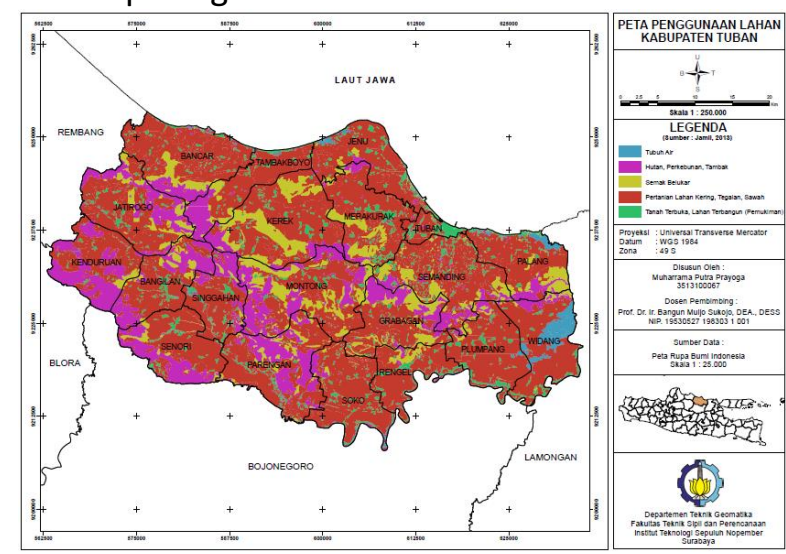

Gambar 9. Peta Klasifikasi Penggunaan Lahan

Sebagian besar kecamatan di Kabupaten Tuban mempunyai tutupan lahan berupa pertanian lahan kering, tegalan/ladang, dan sawah yaitu seluas $125.816,11$ hektar atau $63,70 \%$ dari total wilayah. Untuk kategori tutupan lahan berupa hutan, perkebunan, dan tambak mempunyai luas sebesar 32.490,92 hektar atau 16,45\%, kategori semak belukar sebesar 22.165,20 hektar atau $11,22 \%$, kategori tanah terbuka dan pemukiman seluas $13.331,60$ hektar atau $6,75 \%$ dan tubuh air seluas $3.707,27$ hektar atau 1,88\%.

Klasifikasi penggunaan lahan ini perlu di lakukan ground truth atau uji kebenaran di lapangan. Dari 20 sampel di lapangan, terdapat 16 titik yang sesuai dan 4 titik yang tidak sesuai dengan klasifikasi penggunaan lahan di citra, maka didapatkan tingkat kebenaran uji ketelitian klasifikasi sebesar $80 \%$. Syarat minimal diterimanya uji ketelitian klasifikasi adalah $\geq 80 \%$ [5], sehingga hasil klasifikasi penggunaan lahan citra dapat dikatakan sesuai dengan kondisi di lapangan.

\section{Curah Hujan}

Data curah hujan yang digunakan pada penelitian ini adalah data curah hujan pada tahun 2015 yang didapat dari BMKG Kabupaten Tuban. Klasifikasi curah hujan dapat dilihat pada tabel dibawah ini [11]:

Tabel 7. Klasifikasi Curah Hujan

\begin{tabular}{|l|l|}
\hline Kelas & $\begin{array}{l}\text { Curah Hujan } \\
\text { (mm/tahun) }\end{array}$ \\
\hline 1 & $<1500$ \\
\hline 2 & $1500-2000$ \\
\hline 3 & $2000-2500$ \\
\hline
\end{tabular}

Hasil peta curah hujan adalah sebagai berikut :

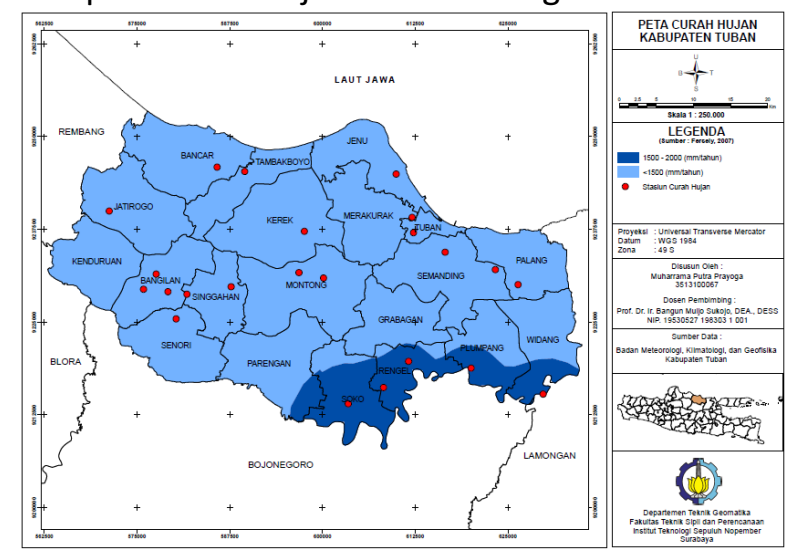

Gambar 10. Peta Curah Hujan

Data curah hujan pada penelitian ini berasal dari 25 stasiun pemantau curah hujan yang tersebar di wilayah Kabupaten Tuban. Data curah hujan ini kemudian diinterpolasi dengan menggunakan metode IDW sehingga menghasilkan peta curah hujan seperti gambar 9 .

Sebagian Besar wilayah Kabupaten Tuban didominasi oleh curah hujan $<1500 \mathrm{~mm} /$ tahun dengan presentase $87,83 \%$. Sedangkan hanya $12,17 \%$ wilayah yang mempunyai curah hujan 1500 - 2000, paling banyak terdapat di wilayah Kabupaten Tuban bagian tenggara seperti Kecamatan Soko, Rengel, Parengan, Plumpang, dan Widang. Untuk curah hujan dengan rentang 2000 2500 tidak terdapat di Kabupaten Tuban.

\section{Hidrogeologi}

Hidrogeologi digunakan pada penelitian ini karena dapat menggambarkan kondisi air bawah tanah, sehingga semakin sedikit jumlah air yang ada di bawah tanah, maka daerah tersebut semakin rawan terhadap kekeringan [2]. 
Klasifikasi hidrogeologi dibagi menurut tipe akuifernya. Klasifikasi hidrogeologi adalah sebagai berikut [12] :

Tabel 8. Klasifikasi Hidrogeologi

\begin{tabular}{|c|ll|}
\hline Kelas & \multicolumn{1}{|c|}{ Tipe Akuifer } \\
\hline 1 & Air Tanah Langka \\
\hline 2 & $\begin{array}{l}\text { Produktivitas Kecil - } \\
\text { Sedang }\end{array}$ \\
\hline 3 & $\begin{array}{l}\text { Produktivitas Sedang } \\
\text { Tinggi }\end{array}$ \\
\hline 4 & Produktivitas Tinggi \\
\hline
\end{tabular}

Hasil peta klasifikasi hidrogeologi bisa dilihat pada gambar dibawah ini :

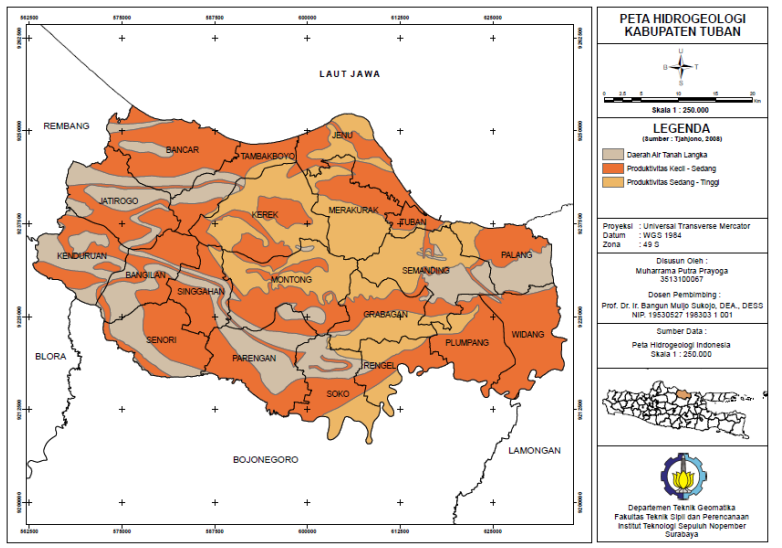

Gambar 11. Peta Hidrogeologi

Dari data hidrogeologi Kabupaten Tuban, hampir setengah wilayah Kabupaten Tuban didominasi tipe akuifer berproduktivitas kecil hingga sedang yaitu mencapai 103.070,05 hektar atau 52,16\% yang menyebar hampir di setiap kecamatan, kemudian akuifer berproduktivitas sedang hingga tinggi sebesar 50.035,22 hektar 25,32\% yang terdapat banyak di bagian tengah wilayah seperti Kecamatan Merakurak, Kerek, Montong, Semanding, dan sekitarnya. Daerah air tanah langka sebesar 44.491,24 hektar atau 22,52\% yang sebagian besar tersebar di bagian barat daya Kabupaten Tuban, Sedangkan untuk akuifer berproduktivitas tinggi tidak terdapat di wilayah Kabupaten Tuban.

\section{Sebaran Daerah Beresiko Kekeringan}

Berdasarkan hasil transformasi citra Landsat 8 yang berupa NDVI, NDWI, LST yang didukung oleh data kondisi fisiografis wilayah seperti curah hujan, hidrogeologi, dan penggunaan lahan, maka tingkat rawan kekeringan di Kabupaten
Tuban dapat terbentuk dengan membaginya ke dalam 5 klasifikasi kekeringan yaitu:

Tabel 9. Klasifikasi Tingkat Kekeringan

\begin{tabular}{|c|l|}
\hline Kelas & $\begin{array}{l}\text { Tingkat } \\
\text { Kekeringan }\end{array}$ \\
\hline 1 & Sangat Rendah \\
\hline 2 & Rendah \\
\hline 3 & Sedang \\
\hline 4 & Tinggi \\
\hline 5 & Sangat Tinggi \\
\hline
\end{tabular}

Hasil peta tingkat kekeringan di Kabupaten Tuban adalah sebagai berikut :

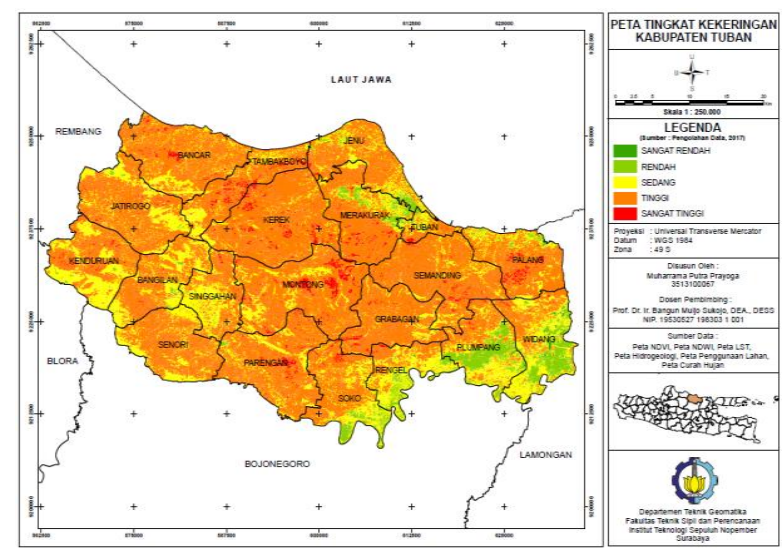

Gambar 12. Peta Tingkat Kekeringan

Dari hasil klasifikasi yang telah dilakukan didapatkan luas masing-masing kelas kerawanan kekeringan seperti tabel berikut :

Tabel 9. Luas Kerawanan Kekeringan

\begin{tabular}{|l|l|l|}
\hline Kategori & Luas (Hektar) & $\%$ \\
\hline Sangat Rendah & 180,48 & 0,09 \\
\hline Rendah & $7.608,58$ & 3,86 \\
\hline Sedang & $57.178,06$ & 29,02 \\
\hline Tinggi & $119.388,50$ & 60,60 \\
\hline Sangat Tinggi & $12.657,89$ & 6,42 \\
\hline
\end{tabular}

Berdasarkan tabel diatas, tingkat kekeringan di Kabupaten Tuban didominasi kategori kekeringan tinggi, kemudian kekeringan sedang, kekeringan rendah, kekeringan sangat tinggi, dan terakhir adalah tingkat kekeringan sangat rendah. Data ini menunjukkan bahwa hasil pengolahan tingkat kekeringan di Kabupaten Tuban menggunakan metode penginderaan jauh dan sistem informasi geografis sesuai dan selaras dengan data indeks resiko bencana yang dirilis BNPB tahun 2013 [1] 
yang menyebutkan tingkat kerawanan kekeringan di Kabupaten Tuban tergolong tinggi.

Daerah yang teridentifikasi mengalami kekeringan disebabkan karena daerah tersebut merupakan daerah dengan volume curah hujan yang tergolong rendah, yaitu hanya $<1500$ $\mathrm{mm} /$ tahun, dan penggunaan lahan yang didominasi oleh tanah terbuka, pemukiman, ladang dan pertanian lahan kering. Kondisi hidrogeologi di Kabupaten Tuban yang tidak terdapat jenis akuifer berproduktivitas tinggi menandakan bahwa hampir di seluruh wilayah Kabupaten Tuban memiliki volume air bawah tanah yang tergolong rendah. Selain itu suhu permukaan tanah juga berperan dominan, dimana wilayah yang rawan terhadap kekeringan mempunyai suhu permukaan yang lebih tinggi dibandingkan daerah lainnya. Hasil tranformasi citra menggunakan algoritma NDVI dan NDWI juga menunjukkan indeks vegetasi dan indeks kebasahan daerah yang teridentifikasi kering mempunyai kerapatan vegetasi dan tingkat kebasahan yang rendah.

\section{KESIMPULAN}

Berdasarkan hasil penelitian dapat disimpulkan:

a. Dalam identifikasi sebaran tingkat kekeringan pada penelitian ini terdapat 6 parameter yang digunakan, yaitu : indeks vegetasi (NDVI), indeks kebasahan (NDWI), suhu permukaan tanah (LST), penggunaan lahan, kondisi hidrogeologi, dan curah hujan.

b. Dalam menentukan tingkat kekeringan, dibagi dalam 5 klasifikasi: kekeringan sangat rendah, kekeringan rendah, kekeringan sedang, kekeringan tinggi, dan kekeringan sangat tinggi.

c. Dari hasil pengolahan data, diketahui bahwa luas tingkat kekeringan sangat rendah adalah 180,48 hektar, tingkat kekeringan rendah adalah 7.608,58 hektar, tingkat kekeringan sedang adalah 57.178,06 hektar, tingkat kekeringan tinggi $119.388,50$ hektar, dan tingkat kekeringan sangat tinggi adalah $12.657,89$ hektar.

\section{UCAPAN TERIMA KASIH}

Kami sampaikan terima kasih kepada kepada Departemen Geomatika ITS yang telah memberikan dukungan administrasi dan pendanaan sehingga penelitian ini dapat berjalan dengan baik dan lancar.

\section{DAFTAR PUSTAKA}

BNPB. 2013. Indeks Rawan Bencana. Jakarta: Badan Nasional penanggulangan Bencana.

Jamil, Dzulfikar Habibi. Tjahjono, Heri. Parman, Satyanta 2013. Deteksi Potensi Kekeringan Berbasis Penginderaan Jauh Dan Sistem Informasi Geografis Di Kabupaten Klaten. Jurnal, 30-37. Semarang : Fakultas Ilmu Sosial, Universitas Negeri Semarang.

Abidin, H. Z., 2002. Survei dengan GPS. Jakarta : Pradnya Paramita Soenarmo, S. H., 2009. Penginderaan Jauh dan Pengenalan Sistem Infromasi Geografi Untuk Bidang IImu Kebumian, Institut Teknologi Bandung (ITB).

Purwadhi, Sri Hardiyanti.2001. Interpretasi Citra Digital. Jakarta: PT Gramedia Widiasarana.

Northrop, A. (2015). IDEAS - LANDSAT Products Description Document. United Kingdom: Telespazio VEGA UK Ltd.

Rudjord, O. and O.D. Trier. 2012. Evalua-tion of FLAASH atmospheric cor-rection. Norwegian Computer Centre. Norwegian. 24p.

Kementrian Kehutanan, 2012. Peraturan Menteri Kehutanan Republik Indonesia Nomor : P.12/Menhut-li/2012, Tentang Tata Cara Penyusunan Rencana Teknik Rehabilitasi Hutan Dan Lahan Daerah Aliran Sungai (Rtk Rhl-Das), Jakarta : Kemenhut

Sugiyono. 2007. Metode Penelitian Administrasi. Bandung : Alfabeta

Haikal, Teungku. 2014. Analisis Normalized Difference Wetness Index (Ndwi) Dengan Menggunakan Data Citra Landsat $5 \mathrm{Tm}$ (Studi Kasus : Provinsi Jambi Path/Row : 125/61). Skripsi. Bogor : IPB.

Fersely. 2007. Identifikasi Indikator Kekeringan menggunakan teknik Penginderaan Jauh. Artikel Skripsi. Bogor: IPB.

Tjahjono, Heri. 2008. Analisis Potensi Wilayah. Semarang: Unnes. 